\section{Eye of the beholder}

SIR-I applaud your decision to publish the letter from R.T. Chelvam (Nature 331, $10 ; 1988)$, as it both gives "scientific creationists" a forum so that they might not claim their ideas are suppressed, and exposes their outrageous scientific prevarications and dubious theology to scrutiny.

In support of his contention that ". . . it takes more gullibility to believe in darwinism than in Genesis", Chelvam quotes Darwin' out of context thus: "to suppose that the eye . . . could have been formed by natural selection, seems, I freely confess, absurd in the highest degree". Darwin's unquoted, following sentence is, "Yet, . . . if numerous gradations from a perfect and complex eye to one very imperfect and simple, each grade being useful to its possessor, can be shown to exist ... and if any variation ... in the organ be ever useful to an animal order changing conditions of life, then the difficulty of believing that a perfect and complex eye could be formed by natural selection . . . can hardly be considered real."

L. v. Salvini-Plawen and Ernst Mayr ${ }^{2}$ have displayed two such graded series of eyes in living prosobranch gastropods and polychaete worms. The body of evidence supporting "creation science" is thus smaller than Chelvam would have us believe.

Chelvam clearly proposes to hold the Creator personally responsible for all the details of biological design, without appreciating the theological problems that result. A notable example is again the human (or any vertebrate) eye, which is so badly bungled that a mortal engineer would be defenceless before a product liability suit. The retina is installed backwards, with the neural connection to the brain interposed between the photoreceptor and the light source. As a result, the neural connections must eventually be gathered together and brought through the retina, resulting in the well-known blind spot that the reader will perceive lateral to the fovea.

This is no trivial defect, but the inevitable product of an evolutionary process constrained at an early stage, when the orientation of the photoreceptors in a simple eyespot was of no significance. Rather than support the concept of an incompetent Creator that follows from biblical literalism, thoughtful theologians see Scripture and the Creator more as did Isaac Newton in his 1681 letter to Thomas Burnett: "As to Moses . . . he described realities in a language artificially adapted to ye sense of ye vulgar. ... Where natural causes are at hand, God uses them as instruments in his works, but I do not think them sufficient for ye creation.

Evolution can be seen as one of the instruments used in the creation. This doctrine raises fewer theological difficulties than does Chelvam's biblical literalism. The initial legal opposition to "scientific creationism" came more from the US Christian community than from the scientific community?. I refer the reader to Conrad Hyers' readable book ${ }^{4}$ for further exposition of the theological issues.

Department of Life Sciences,

Indiana State University

Terre Haute, Indiana 47809, USA

Darwin, C. On the Origin of Species. (A facsimile of the First Edition with an Introduction by Ernst Mayr) 186-187 (Harvard, Cambridge, Massachusetts, 1964).

2. Salvini-Plawen, L. v. \& Mayr, E. in Evolutionary Biology (eds Hecht, M.K. et al.) 10, 207-263 (Plenum, New York. 1977).

. Overton, W.R. Science 215, 934-943 (1982).

4. Hyers, C. The Meaning of Creation: Genesis and Modern Science (Knox, Allanta, Georgia, 1984).

\section{First sentences}

Sir-John Maddox' is no doubt right about the importance of first sentences. I had what I thought was a good one for a Letter to Nature": "Consider an early Precambrian sea on a summer's day". But it was relegated to second sentence by the editors.

\section{Chemistry Department}

A. G. CAIRnS-SMith

The University,

Glasgow G12 8QQ, UK

1. Nature 332, 391 (1988)

2. Cairns-Smith, A. G. Nature 276, 807-808 (1978).

\section{Own goal?}

SIR-As the spread of the AIDS virus (human immune deficiency virus, HIV) has reached epidemic proportions in some communities, there has been much speculation on how this has happened. A number of sources, including your leading article (Nature 331, 376; 1988), have been trying to tell us that sexual promiscuity has had nothing to do with it. I refer to your criticism of Princess Anne's statement that AIDS is an "own goal for mankind". The spread of this virus has been inextricably linked to sexual promiscuity and together with intravenous drug-taking is recognized as one of the two major "amplification" factors clearly responsible for the spread of HIV. The extreme promiscuity of certain groups will lead to an exponential increase in the number of contacts, for example prostitutes in some Central African states and American west coast homosexuals, many of whom claimed that $1,000-2,000$ partners a year was not uncommon. The more mobile and expanding global population of recent decades has also enabled a moderately infectious virus present originally at a very low level in the human population to spread rapidly between separated populations of high risk individuals.

The morality and psychology of promiscuous behaviour is a matter for another discussion. However, it is most likely that if mankind had been monogamous the AIDS epidemic would never have occurred. The question Dr Gallo could have been answering was when?, rather than why now? Certainly the way forward is not to apportion blame but to understand and eradicate the disease. But to pretend that promiscuity is irrelevant to this epidemic is dangerously misleading.

Fergus Davison

Liver Unit,

King's College Hospital,

London SE5 $8 R X, U K$

\section{Flight recorders}

SIR-In the News article "New information throws light on how Yurii Gagarin died" (Nature 331, 292; 1988), the admission by Professor Belotsekovskii that MiG15s did not carry accident data recorders in 1968 was described as "surprising". In fact it would have been very surprising indeed if the Soviet Union had fitted accident data recorders to their fighter trainer aircraft in 1968 , especially as a retrofit. The MiG15 design dates back to the late 1940s.

In the United Kingdom, the accident data recorder 'came of age' in 1965 when a British European Airways Vanguard aircraft crashed at London Heathrow Airport. This was one of only two out of the fleet of twenty aircraft to carry a recorder. The recording was found, by the public inquiry, to provide valuable evidence as to the cause of the crash. As from mid-1966, all new civil British-operated aircraft were required by law to provide 'non-destructible' records of flight data for accident investigation purposes.

Accident data recorders were thus originally introduced so that lessons learnt from accident data could help prevent other tragedies. As the systems have developed, it has become possible quickly to access the data for aircraft maintenance scheduling, providing considerable cost savings over regular maintenance based on flight hours alone. It has thus become cost-effective for military aircraft, but it is only in the 1980 s that an accident data recorder has become a standard requirement for new British fighters and trainers.

Assuming that similar economic imperatives pertain in other countries operating two-seat fighters or trainers, it would be surprising if any such aircraft has had an accident data recorder as standard fit before 1980 .

Island Close,

T.J. SPRigGS

Hayling Island,

Hampshire, UK 